\title{
INTERDEPENDENSI EKONOMI SEBAGAI PENCIPTA PERDAMAIAN ASIA TIMUR
}

\author{
Febry Triantama
}

\begin{abstract}
International relations studies cannot be separated from what is known as conflict and peace. In its development the dynamics of international relations are often colored by the occurrence of these two things. Studies on peace in the realm of international relations have been carried out. These peace studies then produce their own theories in accordance with the tradition of thinking in International Relations. This article argues that economic interdependence is the one that makes peace happens in East Asia between China and Japan and China and South Korea are a result of economic interdependence. Economic interdependence that can be confirmed is through trade and investment (FDI). In conducting analysis, this study uses qualitative research methods with a literature study approach. In library studies, data and information are collected and analyzed to understand the phenomenon being studied
\end{abstract}

Keywords: China, Peace, Economic Interdependence, East Asia

\section{PENDAHULUAN}

Dinamika hubungan internasional di kawasan Asia Timur menjadi sangat menarik untuk dianalisa. Hal ini dikarenakan pada kawasan ini terdapat negara-negara yang memiliki sejarah panjang dalam hal konflik atau perselisihan. Selain itu sejak beberapa dekade ke belakang kekuatan ekonomi tiga negara Asia Timur yakni Tiongkok, Jepang dan Korea Selatan telah diakui dunia. Ketiganya merupakan bagian dari negara yang dikelompokkan sebagai negara dengan tingkat ekonomi maju atau developed countries. Ketiga negara tersebut merupakan anggaota dari G20 yang merupakan negara-negara dengan kekuatan ekonomi 20 besar dunia (G20,

2019). 
Jepang dan Korea Selatan memang telah lebih dulu menjelma menjadi kekuatan ekonomi di Asia maupun Dunia. Jepang dan Korea Selatan tidak membutuhkan waktu yang lama untuk kembali menata kehidupan negaranya setelah melalui masa kelam Perang Dunia II maupun Perang Korea. Jepang dan Korea Selatan ditopang oleh industriindustri dalam negeri yang mampu melakukan ekspansi pasar hingga ke seluruh dunia. Sedangkan pada sisi lain, Tiongkok menjadi rising power setelah terjadinya revolusi ekonomi dibawah kepemimpinan Deng Xiaoping. Pertumbuhan ekonomi Tiongkok mengalami lonjakan yang signifikan serta mengalami industrialisasi yang masif (Chow, 2018; Christofer, 2019). $\quad$ Saat ini produk-produk asal Tiongkok dapat dengan mudah ditemui di berbagai belahan dunia. Hubungan antara Tiongkok dengan dua negara tetangganya di Asia Timur yakni Jepang dan Korea Selatan menjadi menarik untuk dibahas. Hal ini dikarenakan hubungan yang terjalin antara Tiongkok dan Jepang maupun Tiongkok dan Korea Selatan tidak terlepaskan dari dinamika dan menyimpan berbagai potensi konflik yang bahkan berujung pada peperangan. Namun pada kenyataannya semenjak tahun 2000 hingga saat ini tidak pernah terjadi perang (PRIO, 2008) (Uppsala Conflict Data Program, 2019). Dalam kata lain hubungan antar negara yang diangkat di dalam contoh kasus berada pada kondisi damai.

Pada contoh kasus pertama yakni hubungan antara Tiongkok dengan Jepang dapat ditemukan beberapa konflik yang bisa saja berujung pada peperangan. Kedua negara tersebut hingga saat ini memiliki konflik perebutan wilayah. Perebutan wilayah antara keduanya ini terjadi di laut tiongkok timur atau lebih dikenal dengan sengketa pulau senkaku / diayou (Cabestan, 1996). Sengketa yang terjadi antara kedua negara ini bahkan sudah berlangsung sangat lama dan tidak juga terselesaikan hingga saat ini (Dan, 2018). Selain adanya sengketa di laut tiongkok timur, dinamika hubungan kedua negara juga bisa dilihat melalui kacamata sejarah. Merupakan suatu fakta sejarah bahwa dua negara ini 
terlibat dalam peperangan. Tiongkok dan Jepang terlibat perang pada tahun 1894 - 1895 dan juga 1937 - 1945 (Kim, 2012; Seybolt, 2016).

Pada kasus lainnya yakni hubungan antara Tiongkok dan Korea Selatan juga diwarnai oleh dinamika yang bisa saja berujung pada peperangan. Jika dilihat melalui kacamata sejarah, hubungan antara Tiongkok dan Korea Selatan pernah berada pada posisi yang sangat buruk. Hal ini dikarenakan semenjak terjadinya perang Korea yang memisahkan Korea Selatan dan Korea Utara, Tiongkok hanya mengakui keberadaan dan kedaulatan Korea Utara. Kondisi ini terus berlangsung hingga akhirnya pada tahun 1992 kedua negara memutuskan untuk memulai hubungan diplomatik (Liu, 1993). Namun meskipun hubungan diplomatik telah dimulai, Korea Selatan masih tetap menganggap Tiongkok sebagai bentuk ancaman karena Tiongkok merupakan negara sekutu terbesar dan terdekat dari Korea Utara (Chung, 2012). Tiongkok bahkan disebut sebagai negara donor bagi Korea Utara untuk memenuhi kebutuhan-kebutuhan dasar maupun militernya (Nanto \& Manyin, 2011). Persepsi masyarakat Korea Selatan terhadap Tiongkok juga berada posisi dimana sebagian besar masyarakat Korea menganggap Tiongkok sebagai potensi ancaman utama (Chung, 2012). Selain itu, hubungan antara Tiongkok dengan Korea Selatan juga bisa berujung pada peperangan akibat sengketa Socotra Rock (Chung, 2012). Meskipun sejarah hubungan negara-negara tersebut konfliktual dan bahkan masih terdapat beberapa potensi konflik yang memicu perang, pada kenyataannya perselisihan ataupun sengketa tidak pernah berujung pada peperangan. Dengan kata lain hubungan antara Tiongkok dengan Jepang maupun Korea Selatan berada pada kondisi damai.

Oleh karena itu artikel ini akan menganalisa perdamaian yang terjadi di Asia Timur menggunakan interdependensi ekonomi. Pada saat ini memang telah terdapat beberapa penelitian lain yang membahas mengenai pemikiran economic interdependence dan pengaruhnya terhadap konflik (Gartzke, Li, \& Boehmer, 2001; Rosecrance, 1986; McMillan, 
1997). Selain itu terdapat beberapa penelitian yang juga menggunakan Tiongkok sebagai contoh kasus, namun penelitian tersebut membahas menggunakan capitalist peace theory, bukan economic interdependence dan digunakan dalam lingkup hubungan luar negeri yang lebih umum (Weede, 2010). Selain penelitian tersebut terdapat pula penelitian lainnya yang menggunakan economic interdependence terhadap kedekatan politik Tiongkok dengan berbagai negara tetangganya termasuk negara-negara ASEAN, India dan Rusia (Masterson, 2012). Penelitian ini juga akan menggabungkan dua cabang economic interdependence yakni dampak arus perdagangan antar negara dibandingkan dengan keseluruhan ekspor maupun impor dan dampak Foreign Direct Investment.

\section{Kerangka Pemikiran}

\section{Interdependensi Ekonomi}

Kajian dalam tradisi pemikiran liberalisme yang membahas mengenai faktor penyebab perdamaian dunia adalah Interdependensi Ekonomi. Sebagian pemikir liberalisme menyatakan bahwa menjadi faktor penyebab perdamaian adalah adanya saling ketergantungan antar negara dalam bidang ekonomi. Tokoh-tokoh seperti, Robert Keohane, Jack Levy. Andrew Moravscik dan Richard Roscerance merupakan tokoh yang tulisannya menggaungkan pengaruh saling ketergantungan ekonomi dalam perdamaian dunia.

Para pemikir teori Interdependensi Ekonomi mencapai suatu kesepakatan bahwa ketika negara-negara memiliki keterikatan dan saling ketergantungan ekonomi maka perdamaian akan mampu tercipta. Asumsi pemikiran economic interdependence ini disebabkan adanya pertimbangan opportunity cost. Ketika suatu negara telah berada pada kondisi saling ketergantungan dengan segala keuntungan atau manfaat yang diperoleh maka negara akan sangat menghindari perang (Rosecrance, 1986; Keohane \& Nye, 2001). Negara menghindari memilih 
untuk menyelesaikan permasalahan dangan perang atau penggunaan kekerasan karena adanya potensi mendapatkan "hukuman" dari pelaku pasar. Pelaku pasar akan meninggalkan negara yang mementingkan hasrat politiknya dibandingkan dengan keuntungan ekonomi yang bisa dirasakan lebih banyak pihak (Gartzke, Li, \& Boehmer, 2001). Perang dianggap dapat menghilangkan potensi manfaat yang diperoleh dan kemudian berujung pada jatuhnya kondisi ekonomi negara (Polachek, 1980).

Saat ini terdapat beberapa cara yang dapat digunakan untuk mengukur interdependensi atau saling ketergantungan suatu negara dengan negara lain. Beberapa ahli menggunakan perbandingan aktivitas perdagangan yang dalam hal ini ekspor-impor bilateral suatu negara dengan total ekspor-impor negara tersebut (Polachek, 1980). Semakin besar persentase ekspor maupun impor bilateral negara dibandingkan dengan total ekspor-impor negara tersebut ke seluruh dunia maka dapat dikatakan telah terjadi interdependensi ekonomi. Hal ini dikarenakan kedua negara tersebut saling membutuhkan serta mendapatkan manfaat dan keuntungan yang besar.

Selain itu pada saat ini muncul pemikiran bahwa dengan terjadinya globalisasi yang semakin massif maka arus investasi antar negara atau Foreign Direct Investment (FDI) juga perlu dilihat (Blanchard \& Ripsman, 2001;Rosecrance \& Thompson, 2003). FDI menjadi penting untuk dipertimbangkan karena investasi yang dilakukan oleh perusahaan suatu negara ke negara lain dapat membantu menjalankan roda ekonomi negara tersebut. Selain itu, dengan terjadinya investasi maka lapangan pekerjaan untuk masyarakat negara tujuan investasi juga akan terbuka.

Tiongkok merupakan negara yang semenjak tahun 2000 sangat gencar melakukan ekspansi ekonominya ke dunia, termasuk Jepang dan Korea Selatan. Pada tahun 2001 sendiri Tiongkok resmi tergabung ke dalam World Trade Organization yang secara tidak langsung menunjukkan komitmen Tiongkok untuk semakin mengintegrasikan dirinya dalam 
perdagangan dunia. Kondisi Tiongkok yang memiliki jumlah penduduk sangat besar tentunya juga menjadi satu hal yang bisa mempengaruhi aktivitas perdagangan maupun investasi yang berasal dari negara lain karena pangsa pasar yang sangat menggiurkan. Jepang dan Korea Selatan sebagai negara dengan tingkat ekonomi yang sangat baik di Asia Timur lainnya juga tentunya menjadi pangsa pasar yang menarik bagi pelaku usaha Tiongkok.

\section{Globalisasi}

Arus globalisasi dalam beberapa dekade terakhir semakin deras terjadi dan berdampak pada banyak hal. Globalisasi sendiri dapat dikategorikan dalam berbagai aspek kehidupan, yang salah satunya adalah globalisasi ekonomi. Globalisasi ekonomi dicirikan sebagai suatu kondisi dimana arus perdagangan lintas batas menjadi semakin intensif (Kumar, 2003). Selain itu arus perdagangan lintas batas saat ini bahkan semakin mudah terjadi berkat adanya Free Trade Agreements serta keberadaan World Trade Organization (WTO) (Kumar, 2003). Globalisasi ekonomi tidak hanya dapat dilihat dalam aspek perdagangan barang saja. Pada saat ini arus investasi yang terjadi lintas negara juga semakin masif terjadi. Setiap tahunnya berbagai perusahaan di dunia menginvestasikan uangnya di negara lain (Kumar, 2003).

Terjadinya globalisasi ekonomi yang semakin massif ini kemudian juga menimbulkan dampak lain yang berkaitan dengan hubungan internasional. Dampak tersebut adalah menguatnya peran aktor nonnegara terutama Multi National Corporations (MNCs). Negara pada saat ini tidak lagi berperan sebagai satu-satunya aktor dalam hubungan internasional. Bahkan pada saat ini terdapat beberapa MNCs yang kekuatan ekonominya lebih besar dari negara berdaulat (Rodionova, 2016) (Myers, 2016). Selain itu pada era globalisasi seperti saat ini, prioritas tujuan negara juga mengalami perubahan. Pada saat ini negara menempatkan aspek ekonomi terutama pertumbuhan ekonominya 
menjadi prioritas utama (Zagladin, 1999). Negara-negara akan menyediakan iklim domestik maupun internasional yang mendukung tercapainya kebutuhan ekonomi mereka (Zagladin, 1999).

\section{PEMBAHASAN}

\section{Arus Perdagangan}

Saling ketergantungan ekonomi yang terdapat dalam hubungan Tiongkok dengan Jepang dapat dilihat dalam aktivitas perdagangan antar keduanya. Melalui gambar 1 dibawah ini maka akan terlihat bahwasanya Tiongkok memainkan peranan yang sangat vital bagi aktivitas perekonomian Jepang. Jika dilihat pada periode 2000 - 2017 ekspor Jepang ke Tiongkok rata-rata setiap tahunnya mencapai $15.14 \%$ dari total ekspor Jepang ke seluruh dunia. Angka ini melebihi ekspor Jepang ke Negara sekutunya yakni Amerika Serikat (OEC, 2018). maka dapat dikatakan Tiongkok merupakan tujuan utama ekspor industri-industri Jepang, Bahkan Tiongkok berulang kali menduduki peringkat pertama negara tujuan ekspor produk Jepang.

Gambar 1. Grafik Persentase Nilai Ekspor - Impor Jepang ke Tiongkok

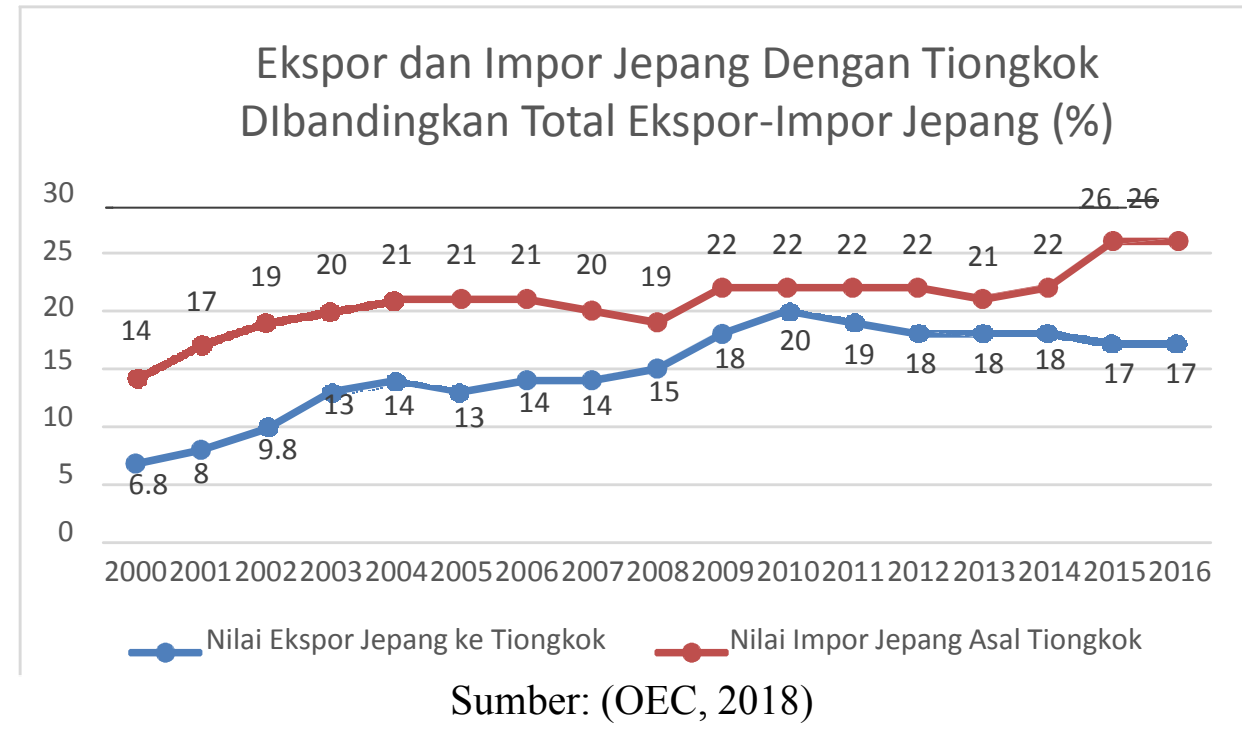

Dengan menggunakan gambar 1 juga dapat terlihat bahwasanya Masyarakat maupun industri-industri jepang juga sangat bergantung dari produk impor yang masuk dari Tiongkok. Hal ini dikarenakan setiap 
tahunnya dalam periode 2000 - 2017 produk impor yang masuk ke Jepang begitu didominasi oleh produk-produk asal Tiongkok. Tiongkok tidak pernah kehilangan mahkotanya sebagai negara dengan nilai ekspor terbesar bagi Jepang. Persentase nilai produk impor asal Tiongkok yang masuk ke Jepang setiap tahunnya rata-rata sebesar 24.7\%, angka ini berarti nyaris seperempat produk impor yang dijual di Jepang berasal dari Tiongkok (OEC, 2018). Nilai impor ini bahkan jauh sekali meninggalkan nilai impor yang berasal dari Amerika Serikat. Selisih keduanya bahkan mencapai 100\% (OEC, 2018).

Jika dilihat pada sisi yang lain yaitu Tiongkok, aktivitas perdagangan dengan Jepang juga berada pada posisi yang besar. Gambar 2 dibawah ini menunjukkan bahwa Jepang merupakan negara yang juga sangat penting bagi Tiongkok. Pada periode 2000 - 2017, Jepang selalu berada pada posisi 3 besar negara asal produk yang diimpor Tiongkok. Pada periode tersebut rata-rata produk impor Tiongkok yang berasal dari Jepang sebesar 13.71\% dari total impor Tiongkok (OEC, 2018). Sedangkan dari sisi ekspor, Jepang juga merupakan negara tujuan utama ekspor Tiongkok. Jepang secara konsisten semenjak tahun 2000 menjadi negara tujuan ekspor terbesar ketiga Tiongkok dengan rata-rata mencapai 9.05\% dari total ekspor Tiongkok (OEC, 2018).

Gambar 2. Grafik Persentase Nilai Ekspor dan Impor Tiongkok ke Jepang

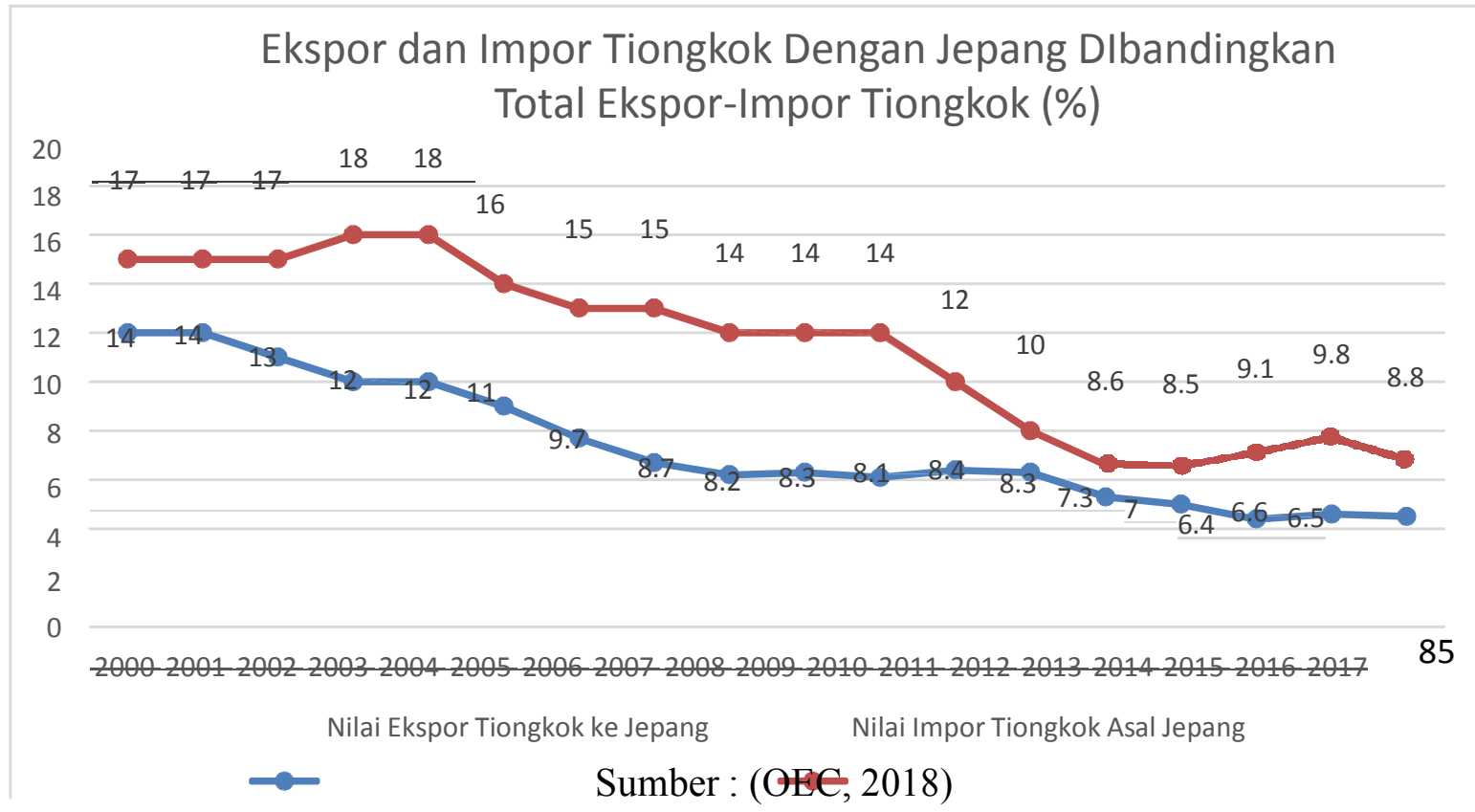


Jika melihat statistik yang telah dijelaskan sebelumnya maka dapat terlihat dengan jelas bahwasanya kedua negara merupakan mitra ekonomi yang sangat strategis dan penting. Arus ekspor dan impor yang terjalin diantara keduanya sangat besar dan tentunya membawa keuntungan ekonomi yang besar bagi pemerintah, pelaku usaha maupun masyarakat kedua negara. Pemerintah kedua negara memperoleh keuntungan dengan tarif bea-cukai maupun bergeraknya roda perekonomian. Pelaku usaha kedua negara juga memperoleh keuntungan dengan semakin luasnya pasar penjualan mereka dan juga potensi keuntungan. Masyarakat kedua negara itu pun juga memperoleh keuntungan dengan semakin banyaknya pilihan produk di pasar yang bisa dipilih dan salin berkompetisi baik harga maupun kualitas.

Gambar 3. Grafik Persentase Nilai Ekspor dan Impor Korea Selatan ke Tiongkok

\section{Ekspor dan Impor Korea Selatan Dengan Tiongkok Dlbandingkan Total Ekspor-Impor Korea Selatan (\%)}

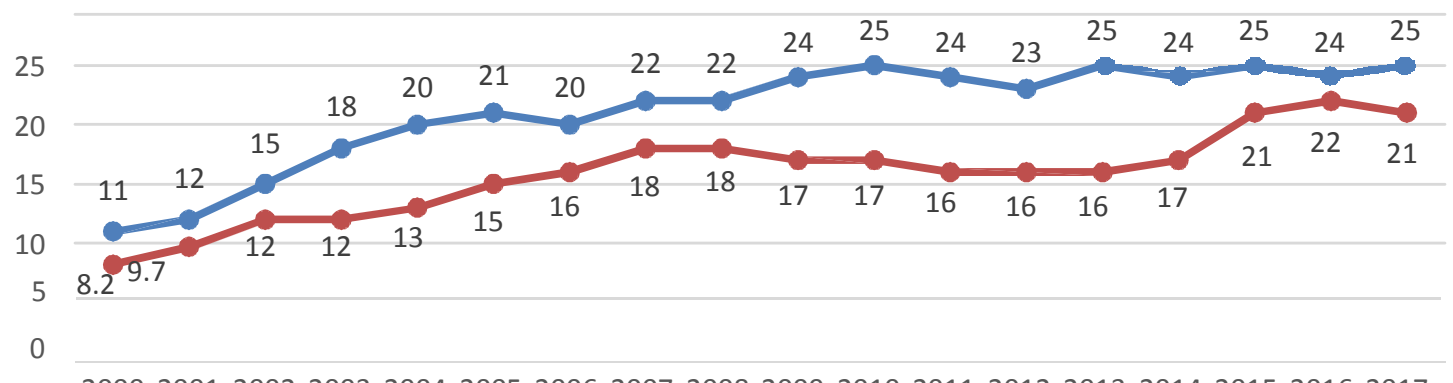

200020012002200320042005200620072008200920102011201220132014201520162017

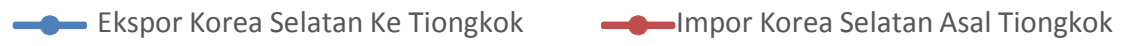

Sumber : (OEC, 2018)

Gambar 3 diatas ini menunjukkan betapa besarnya persentase ekspor dan impor Korea Selatan dengan Tiongkok Setiap tahunnya jika dibandingkan dengan total ekspor-impor Korea Selatan. Melalui gambar 3 diatas juga dapat dikatakan bahwa Korea Selatan cukup bergantung pada produk-produk industri Tiongkok. Hal ini dikarenakan Korea Selatan mengimpor berbagai produk yang berasal dari Tiongkok dengan nilai dan 
volume yang sangat besar. Rata-rata setiap tahunnya Korea Selatan mengimpor 15.83 \% total impornya dari Tiongkok (OEC, 2018). Selain itu, Korea Selatan juga setiap tahunnya menjadikan Tiongkok sebagai pangsa pasar utama mereka, hal ini terbukti pada posisi Tiongkok sebagai negara tujuan ekspor terbesar Korea Selatan dengan rata-rata setiap tahunnya mencapai 21.1\% dari total ekspor Korea Selatan (OEC, 2018). Jumlah ini bahkan dua kali lipat dari ekspor ke Amerika Serikat atau Jepang yang hanya berkisar 10 - 12\% setiap tahunnya (OEC, 2018). Sedangkan pada sisi Tiongkok, Korea Selatan juga merupakan negara yang memiliki posisi sangat penting dan strategis bagi perekonomian.

Gambar 4 dibawah ini akan menunjukkan seberapa besar dan penting Korea Selatan bagi perekonomian Tiongkok dalam hal eksporimpor. Korea Selatan selalu konsisten berada pada peringkat 5 besar negara tujuan ekspor produk-produk yang Tiongkok hasilkan. Setiap tahunnya pada periode 2000 - 2017 volume ekspor Tiongkok ke Korea Selatan rata-rata sebesar 3.9\% dibandingkan total volume ekspor Tiongkok (OEC, 2018). Sedangkan setiap tahunnya Korea Selatan selalu bersaing dengan ketat bersama Jepang maupun Amerika Serikat sebagai negara asal impor Tiongkok terbesar, dengan rata-rata sebesar $10.41 \%$ (OEC, 2018). Hal ini tentunya menunjukkan saling ketergantungan ekonomi antar kedua negara, minimal dalam aspek perdagangan.

Gambar 4. Grafik Persentase Nilai Ekspor dan Impor Tiongkok ke Korea Selatan

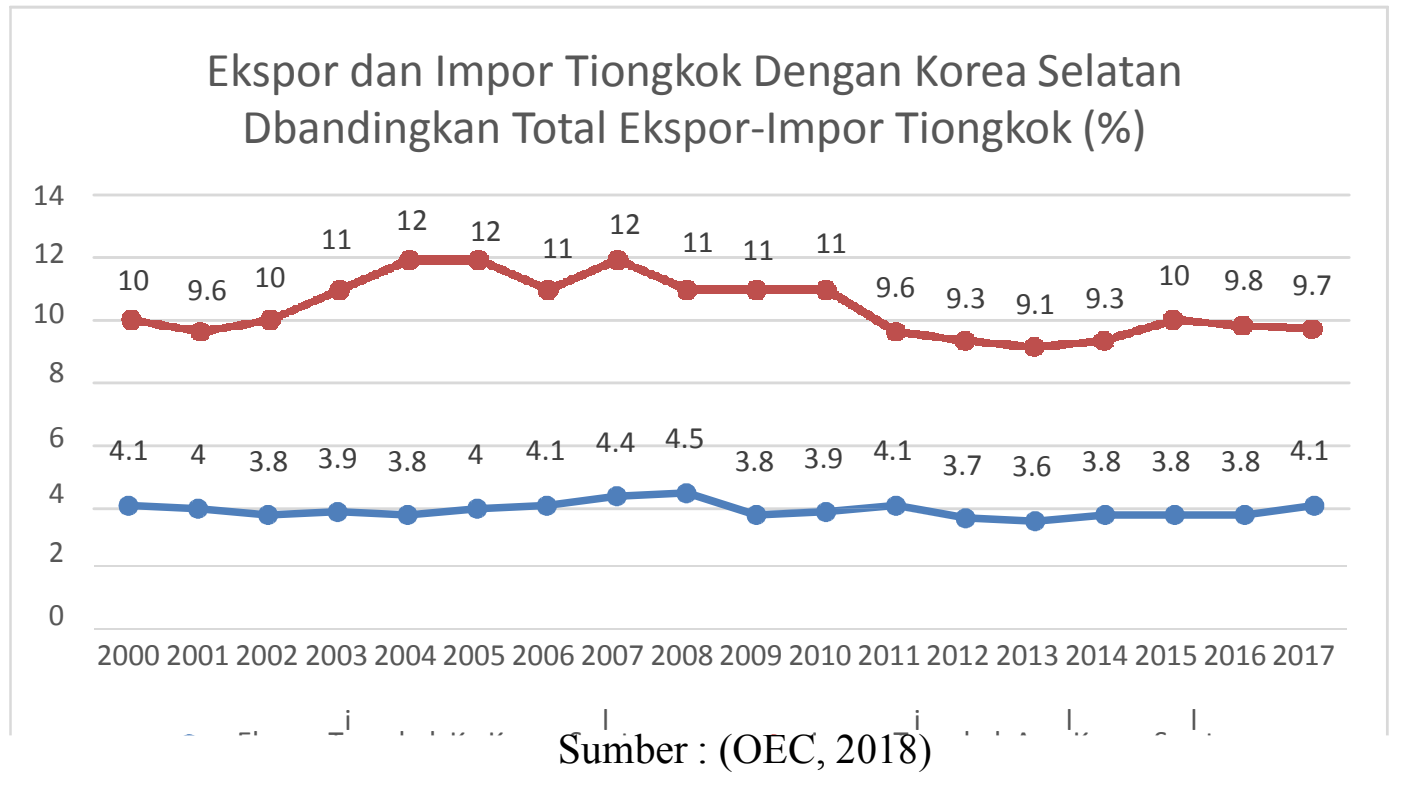




\section{Arus Investasi (FDI)}

Setelah melihat arus perdagangan antar negara-negara contoh kasus maka berikutnya perlu melihat bagaimana arus investasi yang terjadi di antara negara-negara tersebut. Contoh kasus yang pertama akan dilihat adalah antara Tiongkok dengan Jepang. Menurut data yang diolah oleh Japan External Trade Organizations atau JETRO dan dimuat dalam jurnal yang ditulis oleh Min Hua Chiang, Jepang merupakan negara yang sangat gencar melakukan investasi di Tiongkok. Setiap tahunnya perusahaanperusahaan asal Jepang menanamkan modalnya dalam bentuk Foreign Direct Investment ke pasar Tiongkok. Menurut Chiang, hal ini disebabkan oleh beberapa faktor diantaranya kedekatan geografis, upah tenaga kerja yang lebih murah dan tingginya nilai yen di Tiongkok (Chiang, 2019).

Berdasarkan data yang dirilis oleh JETRO pada periode 1998 - 2018 total nilai investasi perusahaan-perusahaan Jepang di Tiongkok mengalami tren peningkatan yang signifikan. Sebagai contohnya adalah pada tahun 2000 nilai investasi hanya mencapai 900 juta USD. Nilai ini kemudian melonjak hingga mencapai 6,6 miliar USD pada tahun 2005 dan 13,6 miliar USD pada tahun 2012. Selain itu nilai investasi Jepang ke Tiongkok setiap tahunnya selalu menjadi bagian besar dari total nilai investasi Jepang ke negara-negara Asia lain dan bahkan tidak pernah berada dibawah 20\%. Gambar 5 dibawah ini akan menunjukkan bagaimana tren investasi yang berasal dari Jepang masuk ke Tiongkok setiap

tahunnya. 
Gambar 5. Grafik Investasi Jepang di Tiongkok Sumber : (Chiang, 2019)

Begitu derasnya arus investasi yang terjadi antara kedua negara ini juga bisa dilihat melalui investasi yang dilakukan pelaku ekonomi Tiongkok ke Jepang. Menurut data yang dirilis oleh Biro Statistik Nasional Tiongkok, investasi yang dilakukan oleh Tiongkok ke Jepang setiap tahunnya mengalami tren peningkatan walaupun juga dalam beberapa tahun mengalami penurunan. Melalui laporan tahunan yang dirilis oleh Biro Sensus Tiongkok, pada periode 2005 - 2017 nilai investasi terendah Tiongkok ke Jepang terjadi pada tahun 2005. Pada tahun 2005 investasi Tiongkok ke Jepang dalam bentuk FDI senilai 17,17 juta USD (National Bureau of Statistics of China, 2006). Sedangkan titik tertinggi terjadi pada tahun 2017 yaitu senilai 444 juta USD (National Bureau of Statistics of China, China Statistical Yearbook 2017). Gambar 6 dibawah ini akan memberikan gambaran mengenai investasi yang dilakukan oleh

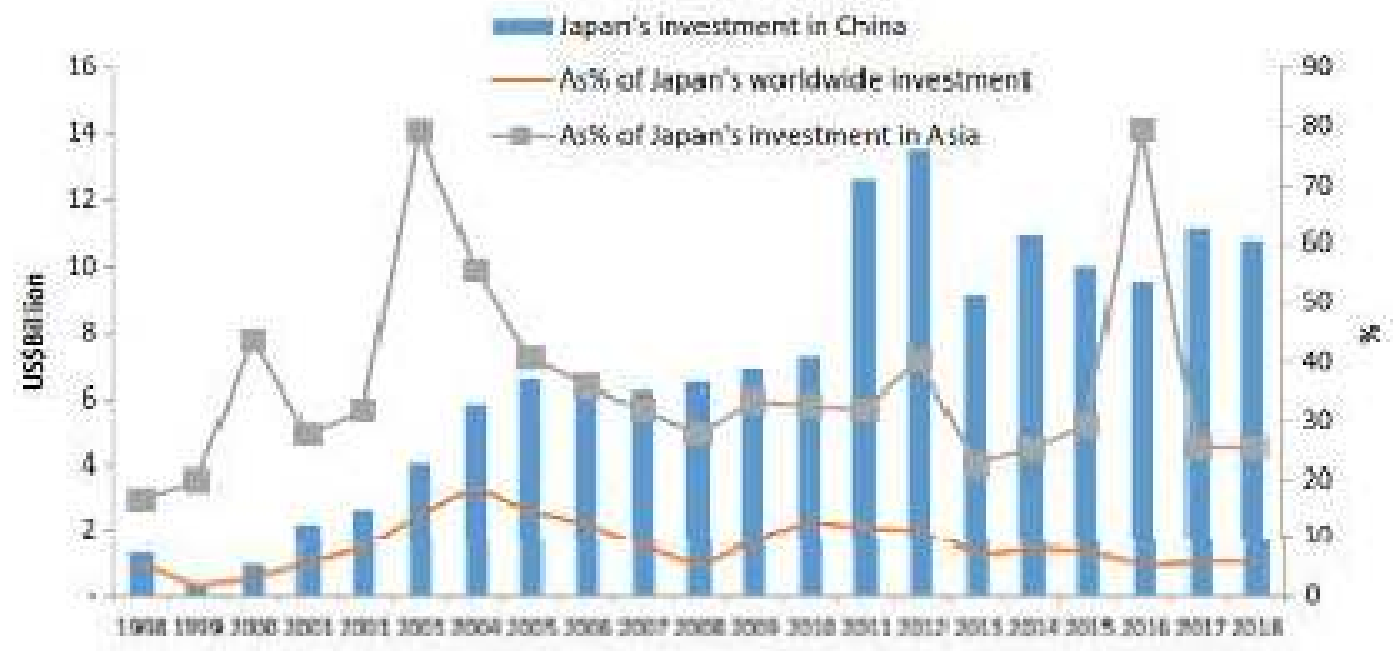

perusahaan-perusahaan Tiongkok ke Jepang dalam bentuk FDI setiap tahunnya. 
Gambar 6. Grafik Investasi Tiongkok di Jepang FDI Tiongkok ke Jepang

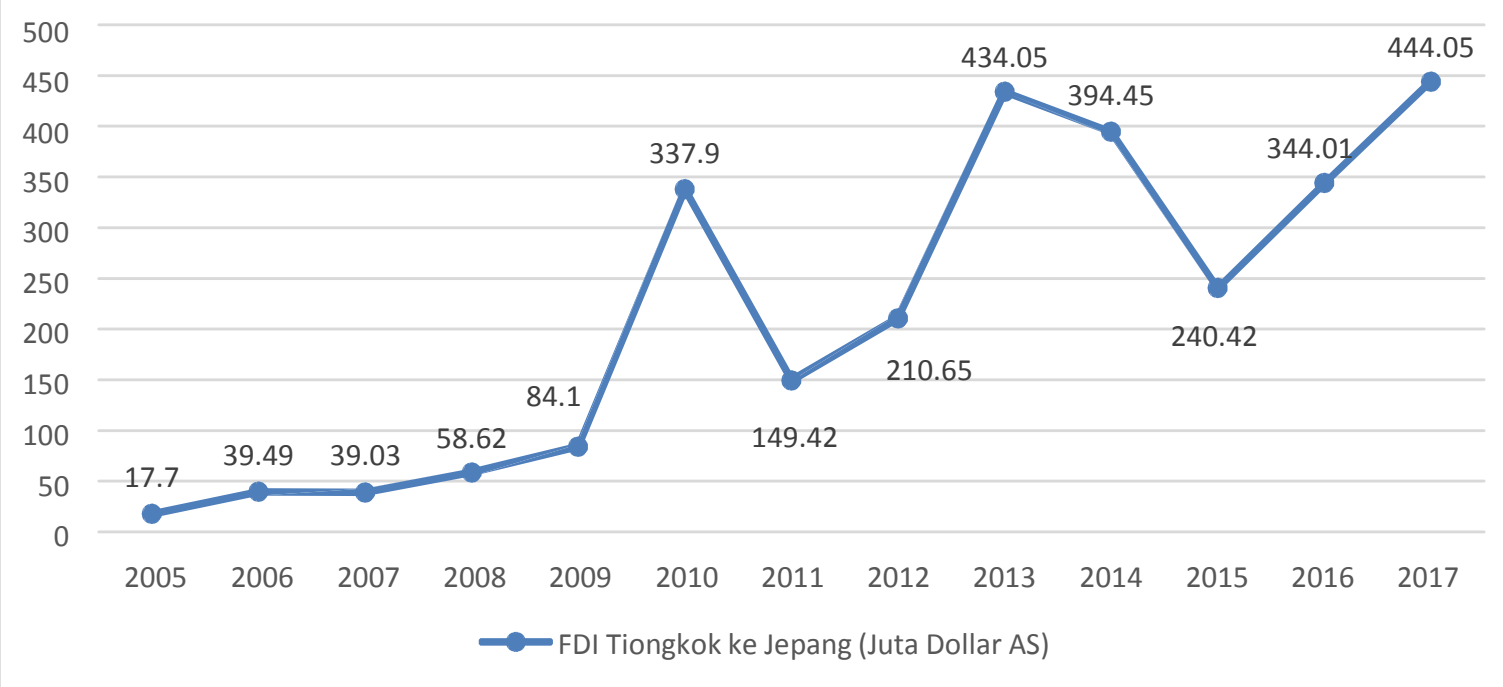

Sumber: Diolah Penulis Dari China Statistical Yearbook

Tidak hanya gencar menanamkan investasi di Jepang, perusahaanperusahaan Tiongkok juga gencar menanamkan modalnya di Korea Selatan. Berdasarkan data statistik bahkan investasi yang berasal dari Tiongkok ke Korea Selatan melonjak sangat signifikan. Pada tahun 2010 investasi yang dilakukan oleh perusahaan asal Tiongkok sebesar 28 Juta USD (Shih, 2015). Angka ini kemudian mengalami lonjakan hingga 450\% pada tahun 2013, yang nilainya mencapai 133 Juta USD (Shih, 2015). Fenomena ledakan investasi Tiongkok ke Korea Selatan terus berlanjut pada tahun 2014, yang lonjakannya mencapai 374\% dengan nilai 631 Juta USD (Shih, 2015). Ledakan ini kembali terulang pada tahun 2018 dimana investasi Tiongkok ke Korea Selatan melonjak hingga 238,9\% dibandingkan investasi pada tahun 2017. Nilai investasi Tiongkok ke Korea Selatan pada tahun 2018 mencapai 2,74 Miliar USD (Suk-yee, 2019).

Perusahaan-perusahan Korea Selatan pun tidak luput dalam melihat Tiongkok sebagai negara yang strategis dan potensial dalam mengembangkan usaha. Semenjak Tiongkok bergabung dengan WTO pada tahun 2001 nilai FDI yang dikeluarkan Korea Selatan ke Tiongkok 
mengalami peningkatan yang signifikan. Gambar 7 dibawah ini akan menunjukkan nilai FDI Korea Selatan ke Tiongkok pada periode 2000 2017. Berdasarkan data yang dihimpun melalui Korea Eximbank tersebut tercatat nilai investasi terbesar terjadi pada tahun 2007 yang sebenarnya tidak lama dari terjadinya perselisihan Socotra Rock pada tahun 2006 dengan nilai sebesar 5,69 Miliar USD (Korea Eximbank, 2019).

Gambar 7. Grafik Investasi Korea Selatan di Tiongkok

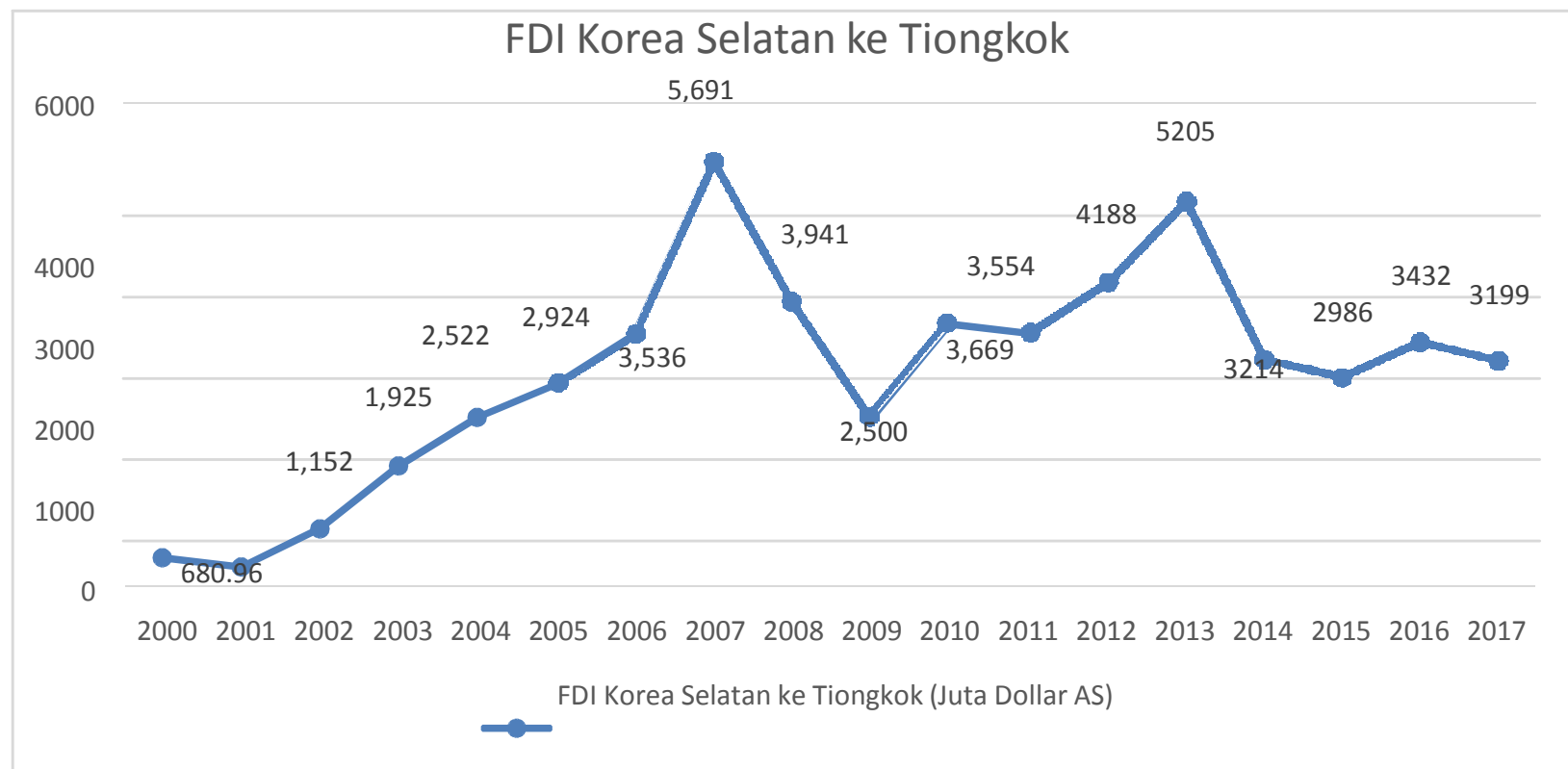

Sumber: Diolah Penulis Dari Korea Eximbank

Nilai FDI Korea Selatan ke Tiongkok juga memiliki porsi yang sangat besar jika dibandingkan dengan total nilai FDI Korea Selatan ke seluruh Asia. Pada tahun 2000 misalnya, nilai investasi Korea Selatan ke Tiongkok sebesar 795,99 Juta USD merupakan 45.22\% dari keseluruhan FDI Korea Selatan di Asia. Persentase ini terus meningkat, pada tahun 2004 mencapai 63.85\%. Pada tahun 2007 yang merupakan tahun dengan nilai terbesar, persentasenya sebesar 46.08\%. Pada tahun 2010 mencapai $35.8 \%$, kemudian pada tahun 2014 menjadi 34.83\% dan pada tahun 2017 menjadi 24.03\%. Meskipun persentase FDI Korea Selatan ke Tiongkok menurun, namun nilainya masih sangat besar dan titik terendahnya terjadi pada tahun

2017. 
Berdasarkan data-data yang berhasil dihimpun maka terlihat bahwasanya dalam interaksi ekonomi antara Tiongkok dengan Jepang maupun Korea Selatan terjadi arus investasi yang sangat besar. Setiap tahunnya ratusan juta atau bahkan miliaran USD diinvestasikan oleh pengusaha-pengusaha yang berasal dari Tiongkok ke Jepang maupun Korea Selatan, dan begitu pula sebaliknya. Oleh karena itu bisa dikatakan bahwa terjadi kondisi saling ketergantungan ekonomi yang sangat kuat diantara negara-negara tersebut. Hal ini sesuai dengan apa yang Roscerance katakan bahwa untuk mengetahui ada atau tidaknya saling ketergantungan ekonomi juga bisa dilihat dalam hal FDI.

\section{Diskusi Temuan}

Pemikiran economic interdependence mampu menjelaskan perdamaian antara Tiongkok dengan Jepang maupun Korea Selatan. Aktivitas perdagangan dalam hal ini volume ekspor dan impor serta investasi Tiongkok dengan Jepang maupun Korea Selatan menunjukkan terdapatnya interdependensi ekonomi. Melalui gambar 1 dan 3 terlihat begitu vital dan strategisnya posisi Tiongkok dalam aktivitas perdagangan Jepang dan Korea Selatan. Bahkan Tiongkok menduduki posisi pertama negara tujuan ekspor maupun negara asal impor. Sedangkan pada gambar 2 dan 4 terlihat bahwasanya Tiongkok turut membutuhkan Jepang dan Korea Selatan dalam melakukan aktivitas perdagangan karena volume perdagangan yang juga sangat besar dan selalu berada peringkat 5 besar. Pada sisi FDI melalui gambar 5 sampai dengan 7 terlihat bahwa investasi yang dilakukan perusahaan yang berasal dari negara-negara tersebut gencar melakukan investasinya.

Menurut pemikiran economic interdependence, ketika interdependensi ekonomi itu telah tercapai maka negara secara rasional akan memilih untuk menghindari perang atau penggunaan kekerasan dalam penyelesaian masalah. Hal ini dikarenakan Tiongkok, Jepang dan Korea Selatan akan menggunakan pertimbangan opportunity cost sebelum 
mengambil kebijakan untuk berperang. Tiongkok selama ini telah mendapatkan banyak keuntungan atau manfaat dari aktivitas perdagangan dengan Jepang dan Korea Selatan. Jika Tiongkok memutuskan untuk memerangi Jepang atau Korea Selatan tentunya aktivitas perdagangan dan investasi akan berhenti. Ketika aktivitas perdagangan maupun investasi tersebut berhenti maka secara otomatis pula keuntungan yang diperoleh oleh Tiongkok selama ini tidak akan bisa didapatkan lagi. Pertimbangan ini juga berlaku bagi Jepang maupun Korea Selatan.

Selain itu, pertimbangan opportunity cost ini juga berlaku dalam ranah investasi atau FDI antar negara. FDI yang selama ini telah terjadi selain dikarenakan alasan-alasan ekonomi seperti upah tenaga kerja, pangsa pasar maupun letak geografis juga merupakan hasil dari hubungan antara Tiongkok dengan Jepang maupun Korea Selatan yang stabil dan damai. Hal ini dikarenakan investor tidak akan mau menanamkan modalnya atau melakukan investasi di negara lain ketika hubungan negara tersebut memiliki potensi untuk berperang yang tinggi. Investor akan mengkhawatirkan keamanan modal atau uang yang telah investasikan di negara tersebut. Oleh karena itu ketika Tiongkok memutuskan untuk berperang dengan Jepang ataupun Korea Selatan maka dapat dipastikan investor akan pergi dari Tiongkok maupun Jepang dan Korea Selatan, dan begitu pula sebaliknya. Hal ini sangat merugikan kondisi ekonomi negara-negara yang berperang.

Selain oleh pertimbangan tersebut, argumentasi yang menyatakan bahwa interdependensi ekonomi menyebabkan perdamaian Tiongkok dan Jepang serta Tiongkok Korea Selatan juga sesuai dengan konteks globalisasi. Globalisasi yang semakin massif terjadi setelah tahun 2000 menjadikan adanya pergeseran prioritas negara. Negara pada era globalisasi disebutkan akan lebih memprioritaskan aspek ekonomi dibandingkan aspek lainnya. Oleh karena itu pilihan Tiongkok untuk tidak berperang dengan Jepang maupun Korea Selatan atau sebaliknya 
dikarenakan kondisi damai saat ini sesuai denga prioritas agenda setiap negara tersebut.

\section{KESIMPULAN}

Perdamaian yang terjadi antara Tiongkok dengan Jepang serta Tiongkok dengan Korea Selatan pada era globalisasi merupakan dampak yang ditimbulkan dari interdependensi ekonomi. Hal ini dikarenakan terbukti Tiongkok memiliki saling ketergantungan ekonomi dengan Jepang dan Korea Selatan. Saling ketergantungan ekonomi ini terlihat dari aktivitas perdagangan yang sangat intensif serta arus investasi yang cukup masif terjadi. Sebagai akibat dari interdependensi ekonomi ini maka negara sebagai aktor rasional akan menggunakan pertimbangan opportunity cost. Selain itu konteks globalisasi juga memberikan keuntungan tambahan bagi pemikiran economic interdependence karena membentuk perilaku negara yang mempriotitaskan aspek ekonomi.

Sebagai catatan bagi penelitian selanjutnya, diperlukan pendalaman lebih lanjut dalam melihat saling ketergantungan ekonomi melalui aktivitas perdagangan lintas batas maupun arus investasi (FDI). Pendalaman dalam arus perdagangan yang dimaksudkan adalah jenis komoditas yang menjadi objek ekspor maupun impor antar negara. Tidak menutup kemungkinan jenis komoditas yang di ekspor maupun impor mempengaruhi derajat interdependensi kedua negara. Hal yang serupa juga diperlukan dalam hal arus investasi antar negara. Pendalaman lanjutan terhadap data arus investasi yang dilakukan menjadi menarik untuk mengetahui apakah ada dampak dari perbedaan jenis usaha yang diinvestasikan terhadap derajat interdependensi ekonomi.

\section{DAFTAR PUSTAKA}

Babones, S. (2017, Oktober 21). China will be driven by 89 million votes this week but don't call it democracy. Diakses dari Forbes: https://www.forbes.com/sites/salvatorebabones/2017/10/21/china- 
will-be-driven-by-89-million-votes-this-week-but-dont-call-itdemocracy/\#6e53ae693369

BBC. (2019, Desember 16). A Quick Guide to the US-China Trade War. Diakses dari BBC: https://www.bbc.com/news/business-45899310

Blanchard, J.-M. F., \& Ripsman, N. M. (2001). Rethinking sensitivity interdependence: Assessing trade, financial, and monetary linkages between states. International Interactions, 95-128.

Cabestan, J.-P. (1996). The New Diaoyu Island Crisis: Who Do the Diaoyu Islands Belong To? China Perspectives, 44-48.

Chiang, M.-H. (2019). Contemporary China-Japan Relations: the Politically Driven Economy Linkage. East Asia, 1-20.

Chow, G. C. (2018). China's economic transformation. In G. Ross, S. Ligang, \& F. Cai, China's 40 Years of Reform and Development: 19782018 (pp. 93-116). Acton: ANU Press.

Christofer, O. (2019). LABOUR MOVEMENT IN CHINA. Jurnal Dinamika Global, 4(01), 178-189.

Chung, J. H. (2012). Korean Views of Korea-China Relations: Evolving Perceptions and Upcoming Challenges. Asian Perspective, 219-236.

Dan, L. (2018, Agustus 8). Diayou Islands Dispute a Chinese Perspective. Diakses dari The Diplomat: https://thediplomat.com/2018/08/diaoyu-islands-dispute-achinese-perspective/

G20. (2019, Desember 1). Participants. Diakses dari G20: https://g20.org/en/about/Pages/Participants.aspx

Gartzke, E., Li, Q., \& Boehmer, C. (2001). Investing in the peace: Economic interdependence and International Conflict. International Organization, 391-438.

Keohane, R. O., \& Nye, J. S. (2001). Power and Interdependence: Word Politics in Transition. Boston: Longman.

Kim, K. H. (2012). The Sino-Japanese War (1894-1895): Japanese National Integration and Constrcution of the Korean "Other". International Journal of Korean History, 1-25. 
Korea Eximbank. (2019, Desember 1). Statistics of Foreign Direct Investment. Diakses dari Korea Eximbank: The Export-Import Bank of Korea: https://stats.koreaexim.go.kr/en/enMain.do

Kumar, V. S. (2003). A Critical Methodology of Globalization: Politics of the 21st Century? Indiana Journal of Global Legal Studies, 87-111.

Liu, H. (1993). The Sino-South Korean Normalization: A Triangular Explanation. Asian Survey, 1083-1094.

Masterson, J. R. (2012). Analysing China's Economic Interdependence and Political Relations With its Neighbours. China Information, 3-33.

McLellan, D. (2005). Globalization in the 21st Century. Theoria: A Journal of Social and Political Theory, 119-127.

McMillan, S. (1997). Interdependence and Conflict. Mershon International Studies Review, 33-58.

Myers, J. (2016, Oktober 19). How do the world's biggest companies compare to world's biggest economies?. Diakses dari World Economic Forum: https://www.weforum.org/agenda/2016/10/corporationsnot-countries-dominate-the-list-of-the-world-s-biggest-economicentities/

Nanto, D. K., \& Manyin, M. E. (2011). China-North Korea Relations. North Korean Review, 94-101.

National Bureau of Statistics of China. (2006). China Statistical Yearbook 2005. Beijing: National Bureau of Statistics of China.

National Bureau of Statistics of China. (China Statistical Yearbook 2017). China Statistical Yearbook 2017. Beijing: National Bureau of Statistics of China.

OEC. (2018, February 1). OEC. Diakses dari OEC: https://oec.world/en/profile/country/ipn/\#Destinations

OEC. (2018, February 1). OEC. Diakses dari OEC: https://oec.world/en/visualize/tree_map/hs92/import/jpn/show/all L2017/

OEC. (2018, February 1). OEC. Diakses dari OEC: https://oec.world/en/visualize/tree_map/hs92/import/chn/show/al $1 / 2017 /$ 
OEC. (2018, February 1). OEC. Diakses dari OEC: https://oec.world/en/visualize/tree_map/hs92/export/chn/show/all $12017 /$

OEC. (2018, February 1). OEC. Diakses dari OEC: https://oec.world/en/visualize/tree_map/hs92/import/kor/show/all $\not 2017 /$

OEC. (2018, February 1). OEC. Diakses dari OEC: https://oec.world/en/visualize/tree_map/hs92/export/kor/show/all $12017 /$

Polachek, S. W. (1980). Conflict and Trade. Journal of Conflict Resolution, 57-78.

PRIO. (2008). Prio Armed Conflict. Diakses dari PRIO: https://www.prio.org/Data/Armed-Conflict/UCDP-PRIO/OldVersions/Armed-Conflicts-Version-4-2008/

Rodionova, Z. (2016, September 13). Worlds largest corporations more money than most countries on earth combined. Diakses dari Independent.co.uk:

https://www.independent.co.uk/news/business/news/worldslargest-corporations-more-money-countries-world-combined-applewalmart-shell-global-justice-a7245991.html

Rosecrance, R. (1986). The Rise of the Trading State: Commerce and Conquest in the Modern World. New York: Basic Books.

Rosecrance, R., \& Thompson, P. (2003). Trade, foreign investment, and security. Annual Review of Political Science, 377-398.

Rudd, K., Clark, H., \& Bildt, C. (2019, Oktober 11). China Trade. Diakses dari Nytimes: https://www.nytimes.com/2019/10/11/opinion/china-trade.html

Seybolt, P. J. (2016). The Second Sino-Japanese War, 1937-1945: The Current Status of Research and Publication in the People's Republic of China, and Prospects and Problems for Foreign Researchers. Republican China, 110-120.

Shih, T. H. (2015, Maret 16). Chinese Investment in South Korea is Skyrocketing. Diakses dari Business Insider: https://www.businessinsider.com/chinese-investment-in-southkorea-is-skyrocketing-2015-3?IR=T 
Smith, A. (1991). Wealth of Nations. New York: Knopf.

Suk-yee, J. (2019, January 4). China's FDI in South Korea Soars 240\% in 2018. Diakses dari Business Korea: http://www.businesskorea.co.kr/news/articleView.html?idxno=2799 $\underline{1}$

UN. (2019, November 5). US - China Trade War is a 'lose-lose' situation for them and the world Warn UN Economists. Diakses dari UN: https://news.un.org/en/story/2019/11/1050661

Uppsala Conflict Data Program. (2019, December 13). UCDP. Retrieved from UCDP: https://ucdp.uu.se/country/710

Weede, E. (2010). The Capitalist Peace and the Rise of China: Establishing Global Harmony by Economic Interdependence. International Interactions, 206-213.

Zagladin, V. V. (1999). The evolution of the state in conditions of globalization. World Futures: Journal of General Evolution, 101-114 